\title{
LEFT CONVEX THORACIC SCOLIOSIS - RETROSPECTIVE ANALYSIS OF 25 PATIENTS AFTER SURGICAL TREATMENT
}

\author{
ESCOLIOSE TORÁCICA SINISTRO-CONVEXA - ANÁLISE RETROSPECTIVA DE 25 \\ PACIENTES APÓS O TRATAMENTO CIRÚRGICO
}

\author{
ESCOLIOSIS TORÁCICA CONVEXA IZQUIERDA - ANÁLISIS RETROSPECTIVO DE 25 \\ PACIENTES DESPUÉS DE TRATAMIENTO QUIRÚRGICO
}

Birgit Deetjen ${ }^{1}$, Ulf Liluenovist ${ }^{2}$, Tobias L. Schulte ${ }^{1}$, Carolin Schmidt ${ }^{1}$, Tobias Lange ${ }^{1}$, Nani Osada ${ }^{1}$, Viola Bullmann ${ }^{1}$

\begin{abstract}
Objective: A retrospective analysis of clinical and radiological data was conducted, with an emphasis on perioperative complications and risk factors and a minimum follow-up period of two years. The postoperative quality of life was assessed using the SRS-22 questionnaire. Methods: Between 1999 and 2009, 25 patients (nine male, 16 female) with LCTS, with a mean age of 13.7 years (2.3-29.8 years), were treated with correction and instrumented fusion at a single institution. Seven patients had congenital scoliosis and 18 patients had noncongenital scoliosis (idiopathic, $n=5$; neuropathic, $n=4$; neoplasm-associated/iatrogenic, $n=3$; secondary to other conditions, $n=$ 6). The average preoperative Cobb angle was $74^{\circ}\left(49-102^{\circ}\right)$. Results: A mean correction of $51 \%$ was achieved postoperatively. The mean Cobb angle at the final follow-up examination was $45^{\circ}\left(19-85^{\circ}\right)$, with a significant loss of correction of $8.8^{\circ}$ on average. Major complications affected five patients (20\%): respiratory insufficiency requiring prolonged intubation, intraoperative cardiac arrest with resuscitation being necessary twice in one patient, persistent clonus, low-grade infection, implant-based complications requiring revision surgery, and adding-on. Minor complications were observed in 22 patients (88\%), mainly gastrointestinal and pulmonary. No cases of paraplegia or death occurred. A noncongenital etiology had been diagnosed before the age of 10 years in all of the patients who had major complications. The best score on the SRS-22 questionnaire was achieved in the domain of pain (87\%), while the poorest was in the domain of self-image (68\%). Conclusions: The results of this study emphasize an increased complication rate in patients with LCTS scheduled for scoliosis surgery. Additional preoperative examinations (MRI, paediatric consultation, cardiologic consultation, pulmonary function test) are mandatory in patients with LCTS. Preoperatively, patients should be informed about the increased cardiopulmonary and neurological risk which may be associated with scoliosis surgery.
\end{abstract}

Keywords: Instrumentation; Complications; Risk factors; Quality of life; Questionnaire.

\section{RESUMO}

Objetivo: Foi realizado estudo retrospectivo baseado em parâmetros clínicos e radiológicos, com ênfase nas complicações, fatores de risco e seguimento mínimo de dois anos. A qualidade de vida pós-operatória foi avaliada por meio do questionário SRS-22. Métodos: No período de 1999 a 2009, 25 pacientes (nove do sexo masculino e 16 do sexo feminino) com idade variando de 2,3 a 29,8 anos (média de idade de 13,7 anos) foram submetidos a tratamento cirúrgico por meio de instrumentação e artrodese. Sete pacientes apresentavam escoliose congenital, cinco apresentavam escoliose idiopática, quatro neuropática, três associada à neoplasia ou iatrogenia, e seis associada a outras doenças. A média dos valores pré-operatórios do ângulo de Cobb foi $74^{\circ}\left(49-102^{\circ}\right)$. Resultados: A média de correção no pós-operatório foi de $51 \%$. Na avaliação de seguimento final, o valor médio do ângulo de Cobb foi $45^{\circ} \operatorname{com}$ variação de 19 a $85^{\circ}$, tendo ocorrido significante perda da correção com o valor médio de $8.8^{\circ}$. Complicações maiores ocorreram em cinco pacientes (20\%): insuficiência respiratória requerendo entubação prolongada, parada cardíaca intraoperatória com ressuscitação, clônus persistente, infecção de baixo grau, complicações com implantes requerendo revisão cirúrgica, e descompensação do tronco. Complicações menores foram observadas em 22 pacientes (88\%), sendo principalmente gastrointestinais e pulmonares. Nenhum caso de paraplegia ou morte ocorreu na série de pacientes estudados. As curvas de etiologia não congênita foram diagnosticadas antes dos 10 anos de idade em todos os pacientes que apresentaram complicações maiores. O melhor escore do questionário SRS-22 foi observado no domínio da dor (87\%), e o pior no domínio da autoimagem (68\%). Conclusões: O resultado do estudo enfatiza as altas taxas de complicação nos pacientes portadores de escoliose torácica sinistro-convexa que são submetidos ao tratamento cirúrgico. Avaliações pré-operatórias adicionais (RNM, avaliação pediátrica, avaliação cardiológica, teste de função pulmonar) devem ser realizadas nesse grupo de pacientes. Antes do procedimento, os pacientes devem ser informados acerca do alto risco de complicações cardiopulmonares e neurológicas associadas ao tratamento cirúrgico da deformidade.

Descritores: Instrumentação; Complicações; Fatores de risco; Qualidade de vida; Questionários.

\section{RESUMEN}

Objetivo: Fue realizado un análisis retrospectivo de datos clínicos y radiológicos, con énfasis en complicaciones perioperatorias y factores de riesgos, y un período mínimo de seguimiento de 2 años. La calidad de vida posoperatoria fue evaluada usándose el cuestionario SRS-22. Métodos: entre 1999 y 2009, 25 pacientes (nueve del sexo masculino, 16 del sexo femenino) con ETCl, con edad promedio de 13,7 años (2,3 - 29,8 años) fueron tratados con corrección y fusión instrumentada, en una única institución. Siete pacientes tenían escoliosis congénita y 18 pacientes tenían escoliosis no congénita (idiopática, $n=5$; neuropática, $n=4$; asociada a neoplasma/iatrogénica, $n=3$; secundaria de otras condiciones, $n=6)$. El ángulo de Cobb preoperativo promedio fue $74^{\circ}\left(49-102^{\circ}\right)$. Resultados: una corrección promedio de $51 \%$

1. Universitätsklinikum Münster, Albert-Schweitzer - Campus 1 Münster, Alemanha.

2. St. Franziskus-Hospital GmbH - Münster, Alemanha. 
fue alcanzada después de la operación. El ángulo de Cobb promedio, en el examen final de seguimiento, fue 45 (19-85), con una pérdida significativa de corrección de 8, $8^{\circ}$ en promedio. Complicaciones graves afectaron a cinco pacientes (20\%): insuficiencia respiratoria que requirió intubación prolongada, paro cardíaco intraoperativo con resucitación siendo necesaria dos veces para un paciente, clonus persistente, infección leve, complicaciones con implantes que precisaron de otra cirugía, y accesorios. Complicaciones de menor importancia fueron observadas en 22 pacientes (88\%), principalmente gastrointestinales y pulmonares. No ocurrieron casos de paraplejía ni de muerte. Una etiología no congénita fue diagnosticada, antes de la edad de 10 años, en todos los pacientes que tuvieron complicaciones graves. La mejor puntuación en el cuestionario SRS-22 fue obtenida en el dominio de dolor (87\%), mientras que la peor se registró en el dominio de la autoimagen (68\%). Conclusiones: Los resultados de este estudio enfatizan una tasa de complicación aumentada en pacientes portadores de ETCI con programación de cirugía de escoliosis. Exámenes preoperatorios adicionales (IRM, consulta pediátrica, consulta cardiológica, prueba de función pulmonar) son obligatorios en pacientes con ETCI. Antes de la operación, los pacientes deben ser informados sobre los mayores riesgos cardiopulmonar y neurológico que pueden estar vinculados a la cirugía de escoliosis.

Descriptores: Instrumentación; Complicaciones; Factores de riesgos; Calidad de Vida; Cuestionarios.

\section{INTRODUCTION}

Adolescent idiopathic thoracic scoliosis usually involves a right convex curve. Left convex thoracic scoliosis (LCTS) is rare r.2. $^{1,2}$ The phenomenon has given rise to numerous theories over the centuries. Handedness, the asymmetric position of the heart and aorta, and side-to-side differences in the anatomy of the lung have been thought to influence the direction of scoliosis convexity ${ }^{3-10}$. The reason for the predominance of right over left convex thoracic curves in adolescent idiopathic scoliosis is still unknown even today.

Many studies have reported that LCTS is associated with a high risk of intraspinal malformations (such as tethered cord syndrome, syringomyelia, and Arnold-Chiari malformation), particularly in the presence of neurological symptoms ${ }^{1,11,12}$. Preoperative magnetic resonance imaging (MRI) of the entire spine should therefore be performed in these patients ${ }^{13-16}$. A possible association between LCTS and numerous diseases, particularly cardiac and neurological conditions, has been a matter of controversy in the literature ${ }^{17-20}$. Clinical experience suggests that surgical treatment of patients with LCTS is difficult and associated with a relatively high rate of complications.

The purpose of this study was to examine clinical and radiological data from patients with LCTS, with special emphasis on perioperative complications and possible risk factors. The study also analyzes a possible association between LCTS and additional pathologies. The patients' postoperative quality of life was assessed using the SRS-22 questionnaire.

\section{MATERIALS AND METHODS}

This study retrospectively reviews clinical and radiological data from 25 consecutive patients who underwent surgical correction of left convex thoracic scoliosis at a single institution from 1999 to 2009. Patients with a main lumbar or main thoracolumbar curve (i.e., with apical vertebra located caudal to the 11th thoracic vertebra) were excluded from the study. Nine of the patients were male and 16 female, with an average age of 13.7 years (range 2.3-29.8 years) at the time of surgery. The follow-up period averaged 2.5 years (range 2.0-5.9 years). The patients were divided into two groups based on the etiology of the scoliosis: 1 , scoliosis of congenital origin and 2 , scoliosis of noncongenital origin. Before surgery, a thorough medical history was taken and a physical examination was carried out in all of the patients. The type of scoliosis, age at the time of initial diagnosis, accompanying diseases, and previous operations were noted.

Twenty-one patients received standard pulmonary function testing preoperatively. In four cases, the test was not possible due to very young age or lack of compliance. The body mass index at the time of admission was calculated for 24 patients.

The following perioperative parameters were documented: duration of surgery, blood loss, and fusion length. Particular attention was paid to perioperative and long-term complications. Complications were classified as either minor or major. Complications that were life-threatening, leading to permanent damage, or necessitating revision surgery, were categorized as major.

Standardized measurements were carried out on the preope- rative and postoperative and follow-up X-rays. Supine right and left bending films were obtained before surgery to evaluate curve flexibility. Primary and secondary curves were measured using the Cobb method ${ }^{21}$. Skeletal maturity was assessed using the Risser sign. Thoracic kyphosis (T4-T12) and lumbar lordosis (L1-L5) were measured on lateral views. Magnetic resonance images of the entire spine were obtained in all of the patients before surgery. The postoperative quality of life at the time of the latest follow-up examination was assessed using the German version of the SRS22 questionnaire ${ }^{22}$.

\section{STATISTICAL ANALYSIS}

Statistical analysis was performed with SPSS software for Windows, version 15.0.1 (SPSS Inc., Chicago, Illinois, USA). Categorical variables are expressed as frequencies and percentages, and continuous variables are presented as means with standard deviation (SD) and range. Before statistical testing, each continuous variable was analyzed exploratively for its normal distribution (Kolmogorov-Smirnov test). Mann-Whitney $U$ tests were used to compare nonparametric variables between independent study groups and the Wilcoxon test for comparison between dependent groups. The chi-squared test and Fisher's exact test were used to analyze categorical variables. The Pearson correlation coefficient was used to evaluate the relationship between two continuous variables. Differences were considered significant at $\mathrm{P}<0.05$.

\section{RESULTS}

\section{Etiology of scoliosis and associated diseases}

With regard to the etiology of the conditions, there were seven patients with congenital scoliosis and 18 with noncongenital scoliosis (idiopathic scoliosis, $\mathrm{n}=5$; neuropathic scoliosis, $\mathrm{n}=$ 4 ; scoliosis secondary to other conditions, $n=6$; neoplasm-associated/iatrogenic scoliosis, $n=3$ ). Intraspinal malformations affected three patients (syringomyelia, $\mathrm{n}=2$; syringomyelia in combination with diastematomyelia, $n=1$ ). There were no cases of intraspinal neoplasm or Arnold-Chiari malformation. Congenital heart disease was observed in three patients (Fallot's disease, dextrocardia in combination with septal defect, mild valvular pulmonary stenosis) (Table 1).

\section{Pulmonary function}

Preoperatively, the maximum vital capacity $\left(\mathrm{VC}_{\max }\right)$ averaged 1.67 I (SD 0.74 I, 0.55-3.44 I). The mean forced expiratory volume $\left(\mathrm{FEV}_{1}\right)$ measured $1.4 \mathrm{I}(\mathrm{SD} 0.58 \mathrm{I}, 0.44-2.7 \mathrm{I})$.

\section{Body mass index $\left(\mathrm{kg} / \mathrm{m}^{2}\right)$}

Body mass index was measured in 24 of the 25 patients. Ten patients had normal weight (average BMl 18.5, SD 2.99), four patients were overweight (average BMI 27.4, SD 3.91) and a further 10 patients were underweight (average BMI 14.6, SD 1.86). All of the underweight patients had scoliosis of noncongenital origin. 
Table 1. Etiology of scoliosis.

\begin{tabular}{|c|c|}
\hline Type of scoliosis & Patients (n) \\
\hline Congenital & 7 \\
\hline Noncongenital & 18 \\
\hline \multicolumn{2}{|l|}{ Idiopathic } \\
\hline Infantile & 3 \\
\hline Juvenile & 1 \\
\hline Adolescent & 1 \\
\hline \multicolumn{2}{|l|}{ Neuropathic } \\
\hline Spinal muscular atrophy type II & 1 \\
\hline Syringomyelia & 2 \\
\hline Unknown neurological disease & 1 \\
\hline \multicolumn{2}{|l|}{ Systemic disease } \\
\hline Type I neurofibromatosis & 1 \\
\hline Fetal alcohol syndrome & 2 \\
\hline Noonan syndrome & 1 \\
\hline CHARGE association & 1 \\
\hline Klippel-Feil syndrome, Fallot's disease & 1 \\
\hline \multicolumn{2}{|l|}{ Neoplasm-associated/iatrogenic } \\
\hline PNET (chest wall, ribs) & 2 \\
\hline Aggressive fibromatosis & 1 \\
\hline Total & 25 \\
\hline
\end{tabular}

\section{Radiographic data}

The average preoperative Cobb angle measured $74.2^{\circ}\left(49-102^{\circ}\right)$ and corrected to $59.8^{\circ}$ on bending films. A mean correction of $51 \%$ to $36.1^{\circ}\left(9-58^{\circ}\right)$ was achieved postoperatively. The mean Cobb angle at the final follow-up examination was $44.9^{\circ}\left(19-85^{\circ}\right)$, with a significant loss of correction of $8.8^{\circ}$ on average.

The preoperative Cobb angle of the lumbar curve averaged $43.4^{\circ}$ $\left(15-100^{\circ}\right)$ and corrected to $28.2^{\circ}$ on bending films. Postoperatively, an average correction of $49 \%$ to $22.3^{\circ}\left(5-68^{\circ}\right)$ was achieved. At the final follow-up examination, the lumbar curve measured $24.4^{\circ}\left(9-61^{\circ}\right)$ on average, with a mean loss of correction of $2.1^{\circ}$.

The Risser sign was measured preoperatively in 23 cases. Thirteen of these patients had Risser sign 0, two had Risser sign II, three had Risser sign III, two had Risser sign IV, and three had Risser sign $\checkmark$. The average thoracic kyphosis measured $45.1^{\circ}\left(6-78^{\circ}\right)$ preoperatively and was corrected by $12.5 \%$ to $37.3^{\circ}\left(8-70^{\circ}\right)$ postoperatively. At the final follow-up examination, the mean thoracic kyphosis measured $45.8^{\circ}\left(6-84^{\circ}\right)$, with a significant loss of correction of $8.5^{\circ}$ (Table 2$)$.

\section{Basic data}

Posterior correction was performed in 20 patients. Due to their young age, two of these patients were treated with growing-rod instrumentation. Two patients underwent anterior correction. In two more cases, combined anterior and posterior instrumentation was necessary. In one patient, an epiphysiodesis of the spine was conducted without instrumentation. A resection of the rib hump was conducted in six patients. The number of fused segments was 10 (SD 3.2, 4-16 segments) on average. The mean intraoperative blood loss was $1077 \mathrm{ml}$ (SD 927, 100-3500 ml). The total operating time averaged $273 \mathrm{~min}$ (SD 92, 135-455 $\mathrm{min}$ )

\section{Perioperative complications}

Perioperative complications were observed in 22 of 25 patients (88\%) (Table 3).

\section{Major complications}

Major complications affected five patients (20\%). One patient with LCTS and syringomyelia had a positive wake-up test with persistent clonus. The correction was immediately released. The clonus
Table 2. Radiometric data

\begin{tabular}{|c|c|c|c|}
\hline Cobb angle $\left({ }^{\circ}\right)$ & Mean & SD & Range \\
\hline \multicolumn{4}{|c|}{ Major thoracic curve $(n=24)$} \\
\hline Preoperative & $74.2^{\circ}$ & $15.9^{\circ}$ & $49-102^{\circ}$ \\
\hline Bending & $59.8^{\circ}$ & $24.3^{\circ}$ & $18-125^{\circ}$ \\
\hline Postoperative & $36.1^{\circ}$ & $13^{\circ}$ & $9-58^{\circ}$ \\
\hline Follow-up & $44.9^{\circ}$ & $15.4^{\circ}$ & $19-85^{\circ}$ \\
\hline \multicolumn{4}{|c|}{ Lumbar curve $(n=23)$} \\
\hline Preoperative & $43.4^{\circ}$ & $18.7^{\circ}$ & $15-100^{\circ}$ \\
\hline Bending & $28.2^{\circ}$ & $21.8^{\circ}$ & $5-88^{\circ}$ \\
\hline Postoperative & $22.3^{\circ}$ & $14.8^{\circ}$ & $5-68^{\circ}$ \\
\hline Follow-up & $24.4^{\circ}$ & $12.7^{\circ}$ & $9-61^{\circ}$ \\
\hline \multicolumn{4}{|c|}{ High thoracic curve $(n=22)$} \\
\hline Preoperative & $32.7^{\circ}$ & $11.5^{\circ}$ & $10-53^{\circ}$ \\
\hline Postoperative & $23^{\circ}$ & $13^{\circ}$ & $6-56^{\circ}$ \\
\hline Follow-up & $28.1^{\circ}$ & $16.8^{\circ}$ & $7-76^{\circ}$ \\
\hline \multicolumn{4}{|c|}{ Thoracic kyphosis $(n=21)$} \\
\hline Preoperative & $45.1^{\circ}$ & $19.3^{\circ}$ & $6-78^{\circ}$ \\
\hline Postoperative & $37.3^{\circ}$ & $16.8^{\circ}$ & $8-70^{\circ}$ \\
\hline Follow-up & $45.8^{\circ}$ & $20.4^{\circ}$ & $6-84^{\circ}$ \\
\hline
\end{tabular}

Table 3. Perioperative complications.

\begin{tabular}{l|c|c|c|c}
\hline Type of complication & \multicolumn{2}{|c|}{ Minor } & \multicolumn{2}{c}{ Major } \\
\hline Cardiovascular & $\mathbf{n}$ & $\%$ & $\mathbf{n}$ & $\%$ \\
\hline Respiratory & 3 & 12 & 1 & 4 \\
\hline Neurological & 11 & 44 & 1 & 4 \\
\hline Gastrointestinal & 3 & 12 & 1 & 4 \\
\hline Infectious & 9 & 36 & 0 & 0 \\
\hline Hematological & 2 & 8 & 1 & 4 \\
\hline Biochemical & 6 & 24 & 0 & 0 \\
\hline Mechanical & 1 & 4 & 0 & 0 \\
\hline Other & 2 & 8 & 3 & 12 \\
\hline Total & 11 & 44 & 0 & 0 \\
\hline
\end{tabular}

persisted postoperatively. Additionally the patient showed a slight quadriceps muscle weakness on the left side and a hyperreflexia of the left lower leg. Postoperative CT scans showed malpositioning of a medial pedicle screw (T6). The screw misplacement was immediately corrected, but the neurologic symptoms persisted postoperatively. One month later, pedicle screw dislodgment (T5) was observed and a second revision operation was performed. A year after the initial operation, severe loss of correction with cranial and caudal adding-on and lower screw dislodgment was diagnosed requiring a third revision operation. Intraoperative tissue samples showed low-grade infection with Staphylococcus aureus. The infection was effectively treated with antibiotics.

One patient with LCTS and type II spinal muscular atrophy suffered respiratory insufficiency requiring prolonged intubation for 19 hours in the intensive care unit.

Two episodes of intraoperative cardiac arrest occurred in one patient with LCTS and Noonan syndrome with no history of cardiac disease. Resuscitation was successful on both occasions. Due to the life-threatening event, the operation was limited to correction and 
instrumentation with a single concave sided rod. Postoperatively, the patient developed a crankshaft phenomenon and adding-on.

One patient with infantile idiopathic scoliosis who was treated with dual growing-rod instrumentation experienced a rod breakage. Posterior instrumentation and fusion of the spine was performed. Postoperatively, the patient complained of pain in the ventral area of the thigh. Computed tomography of the spine revealed a medial pedicle screw malposition (T6) on the right side, with perforation of the spinal canal. A revision operation was immediately conducted and the symptoms receded.

Another patient with infantile idiopathic scoliosis who was treated with a subcutaneous temporary distraction system without fusion experienced three episodes of screw and hook dislodgment requiring revision surgery. The patient also developed hyperkyphosis and spontaneous fusion of the spine.

A noncongenital etiology had been diagnosed before the age of 10 years in all of the patients who had major complications.

\section{Minor complications}

Minor complications - mainly gastrointestinal and pulmonary were observed in 22 patients (88\%) (Table 4).

\section{Postoperative quality of life}

The overall results for the SRS-22 questionnaire at the time of the latest follow-up examination showed an average of $77.5 \%$. The best score was achieved in the domain of pain (87\%) and the poorest in the domain of self-image (68\%) (Table 5$)$.

Table 4. Minor complications

\begin{tabular}{c|l}
\hline \multicolumn{1}{c|}{ Type of complication } & \multicolumn{1}{c}{ Details } \\
\hline Respiratory & $\begin{array}{l}\text { Pleural effusion, pneumothorax, atelectasis, chylothorax } \\
\text { (asymptomatic) }\end{array}$ \\
\hline Cardiovascular & Hypotension, sinus tachycardia, bradycardia, reduced diuresis \\
\hline Gastrointestinal & PONV, intestinal atony, cholecystolithiasis \\
\hline Neurologic & $\begin{array}{l}\text { L5 irritation, pain in the right ventral thigh, temporary clonus } \\
\text { in both feet }\end{array}$ \\
\hline Hematological & Transfusion incident, severe intraoperative blood loss \\
\hline Biochemical & Inappropriate ADH secretion \\
\hline Infectious & Genital mycosis, cystitis \\
\hline Mechanical & $\begin{array}{l}\text { Breakage of the rod, lysis around the screw (no repeat surgery } \\
\text { necessary) }\end{array}$ \\
\hline Other & $\begin{array}{l}\text { Eczema (neck), soft tissue emphysema, weight loss, } \\
\text { pseudobursa, intraoperative fracture of the apical vertebra, } \\
\text { bruise (coccyx), local wound infection, pain in the iliac crest }\end{array}$ \\
\hline
\end{tabular}

$\mathrm{ADH}$, antidiuretic hormone; $\mathrm{PONV}$, postoperative nausea and vomiting.

Table 5. Results of the SRS-22 questionnaire.

\begin{tabular}{l|c|c|c}
\hline SRS-22 domains & Mean (\%) & SD (\%) & Range (\%) \\
\hline Pain & 87 & 14.4 & $48-100$ \\
\hline Function/ activity & 76.8 & 14 & $44-92$ \\
\hline Mental health & 77.7 & 16 & $32-100$ \\
\hline Self-image & 67.7 & 22.9 & $24-100$ \\
\hline Satisfaction & 80 & 23.4 & $30-100$ \\
\hline Total & 77.5 & 14.3 & $44-95$ \\
\hline
\end{tabular}

\section{Case examples}

Case 1. A 13-year-old boy with severe scoliosis secondary to Noonan syndrome and intermittent back pain was referred to the department. Scoliosis had first been noted when he was aged four.

He presented with the typical facial characteristics, short stature, pterygium colli, and pectus excavatum. Long-cassette pos- terior-anterior $\mathrm{X}$-rays showed a $74^{\circ}$ left convex thoracic scoliosis and compensatory $26^{\circ}$ right lumbar and $44^{\circ}$ right upper thoracic curvatures. The lateral radiograph showed thoracic hypokyphosis of $6^{\circ}$ measured from T5 to T12. Magnetic resonance imaging of the entire spine showed no intraspinal abnormalities. Pulmonary function testing revealed severe restrictive pulmonary disease (VC 51\%). After a thorough examination consisting of cardiologic, anesthesiologic, hematologic, and neurologic tests, the patient underwent surgery. He received posterior unilateral instrumentation and fusion from T4 to L4. Two episodes of asystole occurred intraoperatively. The patient was successfully resuscitated both times. Intraoperative transesophageal echocardiography showed no abnormalities. The operation was completed after cardiopulmonary function had stabilized. Due to the intraoperative vital complications, a compromise in the treatment was made and instrumentation was restricted to one side of the spine. A postoperative cardiac consultation revealed no evidence of cardiac disease. We hypothesize that external cardiac compression related to the prone position might have been responsible for the intraoperative cardiac complications in this patient. The postoperative course was uneventful. During a 5-year follow-up period, massive loss of correction occurred, with adding-on, crankshaft phenomenon, and a severe rib hump. Due to the severe intraoperative complications, revision surgery for this patient was not to risk (Figure 1).

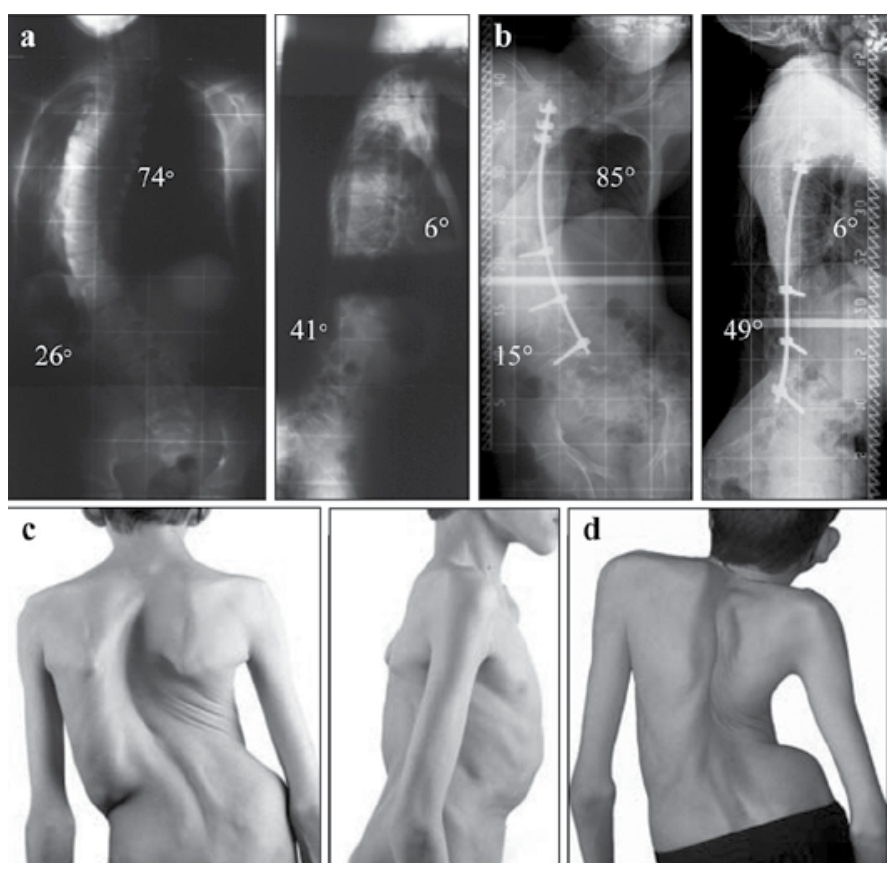

Figure 1. Case 1. A 13-year-old boy with Noonan syndrome and severe left convex thoracic scoliosis. Preoperative (a) and 5-year postoperative (b) posterior-anterior and lateral radiographs. There is massive cranial adding-on at the time of follow-up (b). (c) The clinical photographs before surgery show severe thoracic scoliosis with hypokyphosis. (d) The clinical photograph 5 years after one-rod posterior instrumentation due to major intraoperative complications.

Case 2. A 23-year-old man with aggressive fibromatosis of the posterior mediastinum was treated for severe left convex thoracic scoliosis. Following surgical removal when he was aged 15, the desmoid tumors recurred 3 years later. Surgery was not possible, and the patient was treated with chemotherapy.

Scoliosis progressed during the following years. The radiological examination when he was 23 showed a $97^{\circ}$ left convex thoracic scoliosis and compensatory $50^{\circ}$ right lumbar and $46^{\circ}$ right high thoracic curvatures. The lateral radiograph showed thoracic kyphosis of $32^{\circ}$ measured from T5 to T12. The patient underwent posterior surgery (T3-L1). An anterior release was not performed, due to low 
preoperative vital capacity (VC 42\%). Due to the closeness of the tumor to the neural foramina, limited correction was conducted. Postoperatively, the main thoracic left curve measured $44^{\circ}$, the right lumbar $19^{\circ}$, and the upper right thoracic $25^{\circ}$. The postoperative course was uneventful. At a 2-year follow-up examination, the patient presented in a stable condition with no increase in the magnitude of curvature (Figure 2).
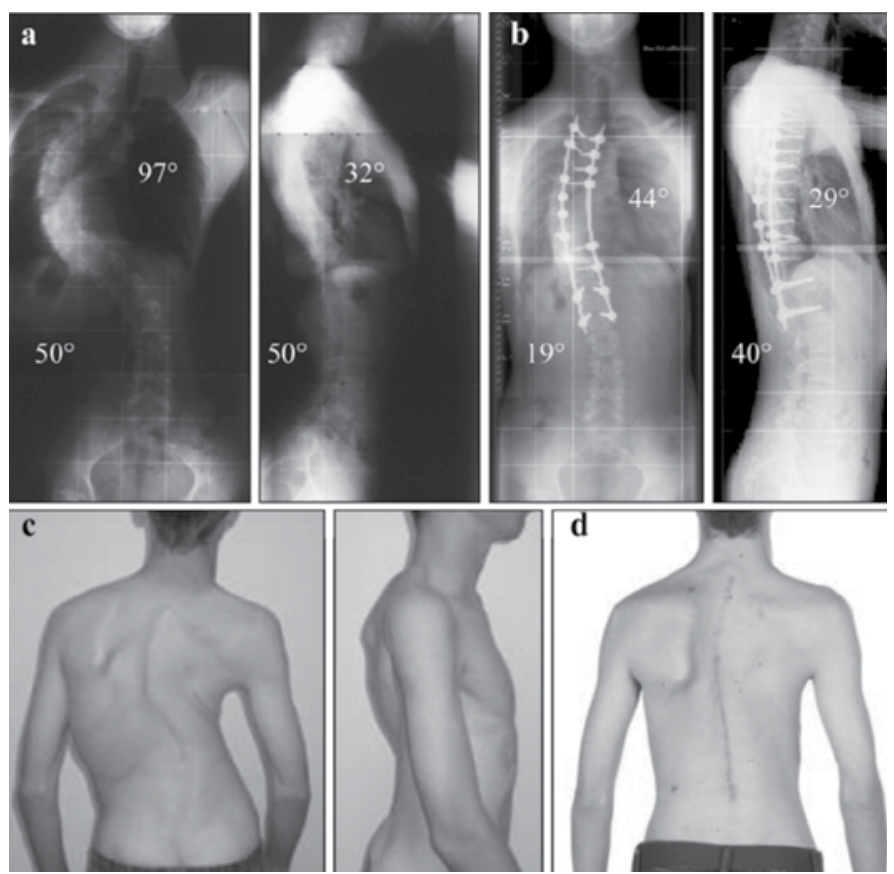

Figure 2 - Case 2. A 23-year-old man with aggressive fibromatosis of the posterior mediastinum and progressive left convex thoracic scoliosis. The preoperative (a) and 2-year postoperative (b) posterior-anterior and lateral radiographs show good coronal plane correction following dorsal instrumentation and fusion. (c) The clinical photographs before surgery show severe thoracic scoliosis and hypokyphosis. (d) The 2-year postoperative clinical photograph shows a well-balanced spine.

\section{DISCUSSION}

\section{Etiology of scoliosis and associated diseases}

Several studies have reported on associated diseases in patients with left convex thoracic scoliosis, many of them focusing on neurological disorders. In 1985, Coonrad et al. ${ }^{1}$ analyzed the data for 27 patients with noncongenital LCTS to determine whether the incidence of intraspinal lesions was sufficiently high to justify the use of myelography and contrast-enhanced computed tomography in these patients. Nine of the 27 patients had a neurogenic etiology, 14 had idiopathic scoliosis, and scoliosis had occurred in combination with other disorders in five cases. According to the authors, myelography and contrast-enhanced CT are necessary in patients with LCTS before idiopathic scoliosis is diagnosed. Barnes et al. ${ }^{13}$ conducted a retrospective analysis of 30 patients with atypical idiopathic scoliosis and found a significant association between left convex thoracic or thoracolumbar scoliosis and hydrosyringomyelia. Schwend et al. ${ }^{23}$ reported on a high incidence of left convex thoracic curves in a group of patients who underwent MRI due to atypical clinical signs. In 1999, Goldberg et al. ${ }^{17}$ analyzed the association between lateralization of scoliotic curves and underlying pathologies. Male gender and juvenile age at onset in females were found to be more reliable signs for associated pathologies than a left thoracic curve pattern.

In the group of patients included in the present study, the rate of associated diseases was remarkably high, with 20 of a total of 25 patients $(80 \%)$ having nonidiopathic scoliosis. Scoliosis of idiopathic origin was present in only five cases. Three of the 25 patients presented with neural axis abnormalities. The scoliosis was neuropathic in four cases. Clinical experience shows that there is a potential association between LCTS and congenital heart disease ${ }^{9}$. Three patients in this study had congenital heart disease, one of whom had dextrocardia. The results of the study suggest that left convex thoracic scoliosis is associated with various diseases.

\section{Pulmonary function}

A high level of standard deviation in the patients' pulmonary function tests was seen in this study. One reason for this might be that four of the patients were suffering from preexisting pulmonary disease, while four others had previously undergone chest wall surgery. One of these patients had had a partial lung excision due to a primitive neuroectodermal tumor in the thoracic wall.

Other reasons for the poor pulmonary function might be the severity of the initial main thoracic Cobb angle and the relatively high degree of curve rigidity in this group of patients. In addition, lung development may have been impaired in seven patients with congenital scoliosis and three patients with infantile idiopathic scoliosis.

\section{Radiometric data}

There have been few reports on radiometric results after surgical treatment of patients with LCTS. In 2005, Crawford et al. ${ }^{24}$ assessed the outcome in 28 patients with adolescent idiopathic LCTS who had undergone either posterior or anterior instrumentation. Preoperatively, the main thoracic curve had an average Cobb angle of $48^{\circ}$ in the anterior group and $62^{\circ}$ in the posterior group. Two years after surgery, corrections of $56 \%$ in the anterior group and $62 \%$ in the posterior group were achieved. Breakwell et al. ${ }^{25}$ reported in 2005 that patients with LCTS have a significantly higher degree of kyphosis and significantly lower curve flexibility in comparison with patients with right convex thoracic scoliosis. In a recent study by Ugrinow et al. $^{26}$, patients with LCTS had a normal thoracic kyphosis of $31^{\circ}$ on average, in comparison with patients with right convex thoracic scoliosis, who had an average hypokyphosis of $22^{\circ}$. According to the authors, this may suggest that a different pathological mechanism is involved in the two types of curvature.

In the present study, the main thoracic Cobb angle was relatively severe before surgery, averaging $74.2^{\circ}$. The flexibility of the main curve, averaging $21.8 \%$, was even more limited in this investigation than in the reports mentioned above ${ }^{25,27}$. The percentage postoperative orrections of the main curve, averaging $50.6 \%$, and correction at the time of follow-up, averaging $37.1 \%$, were relatively low. With regard to thoracic kyphosis, the results of the present study are consistent with the data presented by Breakwell et al. ${ }^{25}$. Thoracic kyphosis measured $45.1^{\circ}$ preoperatively and was corrected to $37.3^{\circ}$ postoperatively. An average hyperkyphosis of $45.8^{\circ}$ was observed during the follow-up.

The relatively small extent of correction in the current study might be caused by primary stiff curves preoperatively and a high loss of correction during the follow-up. In one patient, a decrease in correction was necessary intraoperatively due to neurological complications. In a second case, a life-threatening intraoperative complication resulted in instrumentation from the concave side only. The severity and limited flexibility of the initial main thoracic curve also has to be taken into consideration.

The loss of correction at the time of the latest follow-up, averaging $8.8^{\circ}$, was relatively high in the present study. One reason for this might be the use of different implant types, with hooks as well as pedicle screws. Postoperative adding-on occurred in two patients. Screw/hook dislodgment and rod breakage were observed in two other patients. Another reason for the relatively high loss of correction might be that the majority of patients were skeletally immature before surgery (Risser grades 0-III).

\section{Perioperative complications}

Tremendous advances in scoliosis surgery have been made in recent decades. Segmental pedicle screw instrumentation 
spondylodesis is nowadays a relatively safe technique. Nevertheless, complications cannot be completely avoided.

In 2006, Coe et al. ${ }^{28}$ conducted a multicenter study on complications in scoliosis surgery. The authors analyzed the Scoliosis Research Society (SRS) data on morbidity and mortality in 6334 patients with adolescent idiopathic scoliosis. The total complication rate was $5.7 \%$. Patients who underwent combined anterior and posterior surgery had a significantly higher complication rate in comparison with patients who only underwent anterior or posterior instrumentation (10.2\% vs. $5.2 \% / 5.1 \%)$.

In the present study, the complication rate was relatively high in comparison with the above figures. Minor complications - predominantly respiratory and gastrointestinal - occurred in $84 \%$ of the cases. Major complications threatening the patient's life, causing permanent damage, or necessitating repeat surgery affected $20 \%$ of the patients. In detail, cardiac, respiratory, neurologic, infectious, and mechanical major complications occurred. There were no cases of paraplegia or death. All of the patients in whom major complications occurred had noncongenital scoliosis. The results of this study show that surgical treatment for patients with LCTS is associated with a relatively high complication rate. One reason for this must be seen in the high rate of associated diseases in the present study population.

\section{SRS-22 questionnaire}

The German version of the SRS-22 questionnaire was used to evaluate the patients' quality of life after scoliosis surgery ${ }^{22}$. The response rate was $96 \%$. The average domain score was $77.5 \%$. The best score was achieved in the domain of pain (87\%) and the poorest in the domain of self-image (68\%). Patients with congenital scoliosis reported significantly higher scores in the domain of mental health in comparison with patients who had noncongenital scoliosis (88.6\% versus $73.2 \%)$.

The study's findings indicate that patients with LCTS often have a poor self-image. However, most patients are generally satisfied with the results of surgery.

\section{Limitations of the study}

The results of the present study are limited by the heterogeneity and the small size of the patient population due to the rarity of LCTS. Further limitations concern the use of different surgical techniques and the lack of a comparison series including patients with right convex thoracic scoliosis.

Future studies of idiopathic left convex thoracic scoliosis are needed to obtain a more significant statistical analysis.

\section{CONCLUSION}

The results of our study suggest that surgical treatment of patients with LCTS is associated with an elevated rate of complications. One reason for this must be seen in the high rate of associated pathologies. Additional preoperative examinations (MRI, paediatric consultation, cardiologic consultation, pulmonary function testing) are mandatory in this special patient group.

Preoperatively, patients should be informed about the increased cardiopulmonary and neurologic risk, as well as the high rate of mechanical complications and loss of correction which may be associated with scoliosis surgery.

\section{REFERENCES}

1. Coonrad RW, Richardson WJ, Oakes WJ. Left thoracic curves can be different Orthop Trans. 1985;9:126-7.

2. McCarver $C L$, Levine $D B$, Velaskis K. Left thoracic and related curve patterns in idiopathic scoliosis. J Bone Joint Surg Am. 1971;53:196.

3. Cheselden W. Of the bones of the trunk. In: Cheselden W. The anatomy of the human body. 5th ed. London: Bowyer; 1978. p.24.

4. Del Bigio MR. Are pulmonary factors responsible for the direction of the spinal curvature in idiopathic scoliosis? Med Hypotheses. 1989;28(4):217-8.

5. Farkas A. Physiological scoliosis. J Bone Joint Surg Am.1941;23(3):607-27.

6. Goldberg C, Dowling FE. Handedness and scoliosis convexity: a reappraisal.Spine (Phila Pa 1976). 1990;15(2):61-4.

7. Kouwenhoven JW, Bartels LW, Vincken KL, Viergever MA, Verbout AJ, Delhaas T et al. The relation between organ anatomy and pre-existent vertebral rotation in the normal spine: magnetic resonance imaging study in humans with situs inversus totalis. Spine (Phila Pa 1976). 2007;32(10):1123-8.

8. Miles M. Lateral vertebral dimensions and lateral spinal curvature. Hum Biol. 1944:16:153-71

9. Tallroth K, Lohman M, Heliövaara M, Aromaa A, Knekt P, Standertskjöld-Nordenstam CG. Dextrocardia and coronal alignment of thoracic curve: a population study. Eur Spine J. 2009;18(12):1941-5

10. Taylor JR. Vascular causes of vertebral asymmetry and the laterality of scoliosis. Med J Aust. 1986;144(10):533-5.

11. Padrta BJ, Keenan TL. Left thoracic scoliosis. Etiology and progression. J Pediatr Orthop. 1994:14(5):686.

12. Wu L, Qiu Y, Wang B, Zhu ZZ, Ma WW. The left thoracic curve pattern: a strong predic tor for neural axis abnormalities in patients with "idiopathic" scoliosis. Spine (Phila Pa 1976). 2010;35(2):182-5.

13. Barnes PD, Brody JD, Jaramillo D, Akbar JU, Emans JB. Atypical idiopathic scoliosis: MR imaging evaluation. Radiology. 1993;186(1):247-53.

14. Davids JR, Chamberlin E, Blackhurst DW. Indications for magnetic resonance imaging in presumed adolescent idiopathic scoliosis. J Bone Joint Surg Am. 2004:86(10):2187-95.

15. Redla S, Sikdar T, Saifuddin A. Magnetic resonance imaging of scoliosis. Clin Radiol. 2001;56(5):360-71
16. Spiegel DA, Flynn JM, Stasikelis PJ, Dormans JP, Drummond DS, Gabriel KR, et al. Scoliotic curve patterns in patients with Chiari I malformation and/or syringomyelia. Spine (Phila Pa 1976). 2003;28(18):2139-46.

17. Goldberg CJ, Moore DP, Fogarty EE, Dowling FE. Left thoracic curve patterns and their association with disease. Spine (Phila Pa 1976). 1999;24(12):1228-33.

18. Jordan CE, White RI Jr, Fischer KC, Neill C, Dorst JP. The scoliosis of congenital heart disease. Am Heart J. 1972;84(4):463-9.

19. Luke MJ, McDonnell EJ. Congenital heart disease and scoliosis. J Pediatr. 1968;73(5):725-33.

20. Mejia EA, Hennrikus WL, Schwend RM, Emans JB. A prospective evaluation ofidiopathic left thoracic scoliosis with magnetic resonance imaging. J Pediatr Orthop. 1996;16(3):354-8

21. Cobb J. Outline for the study of scoliosis. AAOS instructional course lectures 1948;5:261-75.

22. Niemeyer T, Schubert $\mathrm{C}$, Halm HF, Herberts T, Leichtle C, Gesicki M. Validity and reliability of an adapted german version of scoliosis research society-22 questionnaire. Spine (Phila Pa 1976). 2009;34(8):818-21.

23. Schwend RM, Hennrikus W, Hall JE, Emans JB. Childhood scoliosis: clinical indications for magnetic resonance imaging. J Bone Joint Surg Am. 1995:77(1):46-53.

24. Crawford A, Babekir N, Lowe T, Betz R, Lenke L, Haher T, et al. Correction of left thoracic curves: a comparison of anterior versus posterior instrumentation. In: Scoliosis Research Society 40th Annual Meeting and Course, Miami, Florida, USA, October 28-30, 2005. p. 216

25. Breakwell LM, Silva FE, Lenke L. Are left thoracic curves more kyphotic and stiffer than right-sided curves? In: Scoliosis Research Society 40th Annual Meeting and Course, Miami, Florida, USA, October 23-30, 2005. p. 257

26. Ugrinow VL, Bastrom T, Varley E, Yaszay B, Newton P Left thoracic curves are not a mirror image of right thoracic idiopathic curves. In: Scoliosis Research Society 44th Annual Meeting and Course, San Antonio, Texas, USA, September 23-26, 2009. p. 61.

27. Crawford A, Babekir N, Lowe T, Betz R, Lenke L, Haher T, et al. Comparison between left and right thoracic curves in idiopathic scoliosis. In: Scoliosis Research Society 40th Annual Meeting and Course, Miami, Florida, USA, October 28-30, 2005. p.238.

28. Coe JD, Arlet V, Donaldson W, Berven S, Hanson DS, Mudiyam R et al. Complications in spinal fusion for adolescent idiopathic scoliosisin the new millennium. A report of the Scoliosis Research Society Morbidity and Mortality Committee. Spine (Phila Pa 1976). 2006; $31(3): 345-9$ 